\title{
Pentingnya Pendidikan Kebencanaan Di Satuan Pendidikan Anak Usia Dini
}

\author{
Mujiburrahman ${ }^{1}$, Nuraeni ${ }^{2}$, Rudi Hariawan ${ }^{3}$. \\ ${ }^{1,2,3}$ Program studi Psikologi Pendidikan dan Bimbingan, FIPP UNDIKMA Mataram \\ ${ }^{1}$ mujiburrahman@ikipmataram.ac.id, ${ }^{2}$ nuraenifip@ gmail.com, ${ }^{3}$ rudiap@ikipmataram.ac.id
}

\begin{abstract}
Abstrack. Artikel ini menjelaskan pentingnya pendidikan kebencanaan di satuan pendidikan anak usia dini. Untuk tujuan tersebut penulis menggunakan metode kepustakaan. Indonesia merupakan negara dengan rawan bencana, perlu menerapkan pendidikan kebencanaan pada lembaga pendidikan anak usia dini supaya peserta didik memiliki pengetahuan dan pemahaman tentang kebencanaan. Penerapan pendidikan kebencanaan pada lembaga pendidikan anak usia dini sebagai upaya dalam memberikan pengetahuan dan pemahaman sejak dini pembelajaran siaga bencana. Melalui pendidikan kebencanaan peserta didik diharapkan mampu berpikir dan bertindak secara cepat dan tepat dalam menghadapi bencana.
\end{abstract}

\section{Kata kunci: Pendidikan Kebencanaan, Paud}

\section{PENDAHULUAN}

Indonesia merupakan negara dengan rawan bencana alam baik disebabkan faktor geologi maupun meteorologi.Bencana alam geologi karena Indonesia terletak pada pertemuan tiga lempeng tektonik bumi, yaitu Lempeng Eurasia, Indo-Australia, dan Samudera Pasifik. Pertemuan tiga lempeng ini menyebabkan Indonesia rawan bencana gempa bumi dan letusan gunung api. Sehingga menyebabkan Indonesia termasuk pada bagian dari Ring of Fire dunia.Bentuk Wilayah Indonesia yang sekitar 70\%-nya berupa lautan menyebabkan Indonesia sangat rawan bencana tsunami yang disebabkan oleh gempa tektonik maupun gempa vulkanik.

Begitu pula, posisi Indonesia yang terletak di daerah tropis dengan curah hujan yang tinggi sangat berpotensi bencana longsor, banjir, dan angin puting-beliung pada musim hujan, dan bencana kekeringan pada setiap musim kemarau. (jp_geografi@upi.edu).

Bencana besar yang tidak hanya menimbulkan kerusakan sarana fisik, kerugian ekonomi yang besar tetapijuga menelan korban jiwa dan trauma yang berkepanjangan, hal ini sangat menyadarkan bahwa kita hidup di daerah rawan bencana. Seperti bencana gempa bumi dan tsunami yang terjadi di Aceh 2004, bencana gempa bumi di Jogjakarta 2006, bencana tsunami Pangandaran 2006, bencana gempa bumi Padang 2009, dan terbaru di tahun 2018 lalu gempa bumi di Lombok dan PaluDonggala yang disusul tsunami dan liquifaksi, dan bencana tsunami di Selat Sunda pada akhir tahun 2018. Kejadian bencana alambesar ini semakin menyadarkan betapa pentingnya pendidikan kebencanaan di Indonesia ${ }^{2}$.

Gempa bumi yang terjadi di Lombok menyisakan beban yang sangat berat bagi seluruh elemen masyarakat yang ada di Nusa Tenggara Barat, lebih khusus masyarakat Lombok Utara, berdasarkan data BNPB bahwa Kabupaten Lombok Utara merupakan kabupaten terdampak gempa paling parah, rumah dan fasilitas umum lainnya rusak berat. Berdasarkan data yang disajikan oleh CNN Indonesia yang bersumber dari data Sekretariat Nasional Pendidikan Aman Bencana (SNPAB) pada tanggal 13 Agustus 2018, Khusus di Lombok Utara, 471 orang meninggal, ribuan orang luka-luka, 23.098 rumah hancur, 169 satuan pendidikan rusak, 112 masjid roboh, sebanyak 1.117 ruang kelas dan 407 ruangan pendukung, sedangkan 215 ruang kelas mengalami kerusakan kategori sedang ringan. 90 persen sekolah di Lombok Utara rusak. Sejumlah 23.822 siswa SD dan 7.304 siswa SMP berada di pengungsian dan tidak bisa mengikuti proses belajar mengajar normal dalam waktu yang cukup lama. Terkait dengan gempa sebelumnya yang terjadi di wilayah Lombok Timur tanggal 29 Juli 2018 berdasarkan data dari pihak Badan Nasional Penanggulangan bencana (BNPB) yang dipublikasikanpada lamanWikipedia menyebutkan bahwa sebanyak 20 orang meninggal dunia salah satu warga negara Malaysia serta 401 orang lainnya mengalami luka-luka. Sedikitnya 10.062 rumah ikut rusak. 
Gempa bumi dan liquifaksi di PaluDonggala mengakibatkan ribuan rumah, tempat ibadah, sekolah dan fasilitas umum hancur dan rusak total, berdasarkan data BNPB yang dilaporkan oleh tirto.id mencatat per 21 Oktober 2018 bahwa sebanyak 2.256 orang meninggal dunia di 4 daerah di Sulawesi Tengah. Sementara itu sebanyak 1.309 orang dinyatakan hilang, 4.612 orang luka-luka dan 223.751 orang telah mengungsi di 122 tempat.

Kemudian gelombang tsunami yang melanda selat sunda pada 22 Desember 2018 yang disebabkan oleh letusan anak gunung krakatau menghantam daerah pesisir Banten dan Lampung, sedikitnya 426 orang meninggal dan 7.202 terluka dan 23 orang hilang akibat peristiwa tersebut.

Rangkaian peristiwa tersebut memberikan banyak pengalaman empiris tentang kejadian bencana yang membawa korban.Masyarakat pada umumnya memiliki pengetahuan dalam memprediksi dan melakukan mitigasi bencana alam.Berdasarkan hal tersebut, disadari bahwa pemahaman tentang bencana alam harus dimiliki oleh semua orang.Diperlukan upaya konkret dalam memahami dan mengantisipasi kondisi ala secara terpadu.Salah satu wujudnya, melalui upaya pengurangan risiko bencana yang berbasis pendidikan.Pendidikan menjadi salah satu sarana yang efektif untuk mengurangi risiko bencana dengan memberikan pemahaman kepada pendidik maupun peserta didik.

\section{PEMBAHASAN}

Pendidikan merupakan usaha sadar dan terencana untuk mewujudkan suasana belajar dan proses pembelajaran agar peserta didik secara aktif mengembangkan potensi dirinya untuk memiliki kekuatan spiritual keagamaan, pengendalian diri, kepribadian, kecerdasan, akhlak mulia, serta keterampilan yang diperlukan dirinya, masyarakat, bangsa dan negara (UU No. 20 tahun 2003 tentang SISDIKNAS). Melalui pendidikan harapannya peserta didik mengalami perubahan ke arah yang lebih baik, baik dari pengetahuan, sikap, maupun ketermpilan.

Dalam Permendikbud Nomor 1372014 diungkapkan bahwa program PAUD merupakan integrasi dari layanan pendidikan, pengasuhan, perlindungan, kesehatan dan gizi yang diselenggarakan dalam bentuk satuan atau program $^{5}$.

Pendidikan anak usia dini merupakan salah satu bentuk penyelenggaraan pendidikan yang menitikberatkan pada peletakan dasar ke arah pertumbuhan dan 6 (enam) perkembangan: agama dan moral, fisik motorik, kognitif, bahasa, sosial - emosional, dan seni, sesuai dengan keunikan dan tahaptahap perkembangan sesuai kelompok usia yang dilalui oleh anak usia dini seperti yang tercantum dalam Permendikbud 137 tahun 2014 tentang standar nasional PAUD. (http://id.m.wikipedia.org).

Saat ini penyelenggaraan pendidikan anak usia dini mengacu pada kurikulum nasional pendidikan anak usia dini yang ditetapkan berdasarkan Permendikbud nomor 146 tahun 2014 dikenal dengan kurikulum 2013 PAUD. Kurikulum tersebut bersifat umum dan menjadi rujukan bagi seluruh lembaga pendidikan anak usia dini yang tersebar secara nasional di seluruh wilayah Indonesia, satuan pendidikan anak usia dini harus mengembangkannya menjadi kurikulum operasional yang mengacu sesuai dengan kondisi dan kekhususan atau potensi yang dimiliki oleh lembaga pendidikan anak usia dini itu sendiri atau tingkat daerah.

Lembaga pendidikan anak usia dini merupakan salah satu lembaga yang dapat berperan dalam kegiatan pengurangan risiko bencana yang memiliki kewajiban dalam memberikan pemahaman, menumbuhkan kesadaran kesiapsiagaan bencana dan mencerdaskan anak-anak generasi penerus bangsa sejak dini.

Bencana merupakan peristiwa atau rangkaian peristiwa yang mengancam dan mengganggu kehidupan dan penghidupan masyarakat, yang disebabkan baik oleh faktor alam dan/atau faktor non alam, maupun faktor manusia, sehingga mengakibatkan timbulnya korban jiwa manusia, kerusakan lingkungan, kerugian harta benda, dan dampak psikologis ${ }^{8}$.

Dalam Undang-undang Republik Indonesia Nomor 24 Tahun 2007 bahwa, Bencana dikategorikan menjadi 3 (jenis) jenis bencana, yakni:

1. Bencana alam adalah bencana yang diakibatkan oleh peristiwa atau serangkaian peristiwa yang disebabkan oleh alam antara lain berupa gempa bumi, tsunami, gunung 
meletus, banjir, kekeringan, angin topan, dan tanah longsor.

2. Bencana non alam adalah bencana yang diakibatkan oleh peristiwa atau rangkaian peristiwa non alam yang antara lain berupa gagal teknologi, gagal modernisasi, epidemi, dan wabah penyakit.

3. Bencana sosial adalah bencana yang diakibatkan oleh peristiwa atau serangkaian peristiwa atau serangkaian peristiwa yang diakibatkan oleh manusia yang meliputi konflik sosial antar kelompok atau antar komunitas masyarakat, dan teror.

Dalam Undang-undang No. 24 tahun 2007 disebutkan bahwa penyelenggaraan penanggulangan bencana adalah serangkaian upaya yang meliputi penetapan kebijakan pembangunan yang berisiko timbulnya bencana, kegiatan pencegahan bencana, tanggap darurat, dan rehabilitasi. Kegiatan penanggulangan bencana dilaksanakan secara terus menerus sebelum terjadi bencana, pada saat bencana dan setelah terjadi bencana.

Siklus kegiatan penanggulangan bencana yang dilaksanakan di Indonesia saat ini merupakan hasil kajian dan pengalaman empiric yang terjadi, sehingga tidak hanya berfokus pada saat terjadi bencana, namun juga pada tahap pra-bencana dan sesudah bencana terjadi.

a. Kegiatan pra-bencana merupakan serangkaian kegiatan pendidikan dan/atau pembelajaran pada anak usia dini yang berhubungan dengan pemahaman kesiapsiagaan dalam menghadapi bencana. Kegiatan ini ditujukan untuk mengurangi (mereduksi) potensi bahaya/kerugian yang mungkin timbul ketika bencana. Pada pendidikan pra bencana dibagi menjadi tiga bagian sesuai dengan kondisi yang dihadapi pada saat bencana, antara lain adalah: pencegahan, mitigasi dan kesiapsiagaan.

b. Tanggap darurat bencana merupakan serangkaian kegiatan yang dilakukan dengan segera pada saat kejadian bencana untuk menangani dampak buruk yang ditimbulkan, yang meliputi kegiatan penyelamatan dan evakuasi korban, harta benda, pemenuhan kebutuhan dasar, perlindungan, pengurusan pengungsi, penyelamatan, serta pemulihan prasarana dan sarana. c. Pasca bencana merupakan kegiatan yang dilakukan untuk memulihkan (merehabilitasi) dan membangun kembali (merekonstruksi) berbagai akibat yang ditimbulkan setelah bencana terjadi.

Posisi pendidikan kebencanaansama persis dengan pendidikan Lingkungan. Artinya peserta didik bukan hanya dituntut punya sikap dan keterampilan untuk penyelamatan diri dalam rangka meminimkan korban jiwa. Pendidikan kebencanaanakan berjalan sesuai dengan harapan apabila seluruh komponen pengetahuan, sikap, dan keterampilan dapat dilaksanakan dengan baik. oleh karena itu, keberhasilan pendidikan kebencanaan hanya bisa dilakukan melalui pembiasaan.

Pendidikan bencana bukan hanya tanggung jawab pemerintah melalui BNPB atau guru yang mengajarkan persebaran daerah potensi bencana, tetapi juga merupakan tanggungjawab orang tua, masyarakat, pemuka agama, lembaga swadaya masyarakat, generasi muda dan bahkan politisi ${ }^{12}$.

Dengan banyaknya bencana yang terjadi di Indonesia, maka menjadi penting pendidikan kebencanaan dilakukan sejak dini, dan hal ini bisa dilakukan dengan mendidik para guru PAUD tentang pendidikan kebencanaan yang nantinya dapat disampaikan pada anak melalui kegiatan main sesuai prinsip pembelajaran di satuan pendidikan anak usia dini. Upaya pemberianpendidikan kebencanaan sejak dini merupakan tindakan penting dan mendasar yang bukan hanya sebagai tindakan pengembangan atau pengayaan kurikulum semata, tetapi juga merupakan tindakan preventif bagi kehidupan setiap anak dalam menghadapi fenomena tersebut di masa yang akan datang, sehingga ketika dihadapkan pada kejadian nyata setiap anak telah memiliki kesiapan yang optimal dalam menghadapinya.

Dengan banyaknya bencana yang terjadi akhir-akhir ini hampir merata terjadi di seluruh wilayah indonesia, baik bencana banjir, tsunami, gempa bumi, longsor, akibat letusan gunung berapi, dan sebagainya. Bahkan, pada beberapa wilayah kondisi tersebut menjadi bagian dari kehidupan yang tidak terpisahkan dari kehidupan sehari-hari, karena berlangsung lama, tiba-tiba terjadi serta menjadi kejadian rutin, seperti bencana banjir. Hal tersebut, jika di diperhatikan dengan cermat bahwa dari waktu ke waktu semakin sering terjadi dan 
memiliki kecenderungan semakin meluasnya areal yang ter-dampak.

Kondisi tersebut, bukan hanya berdampak pada kehidupan masyarakat secara umum, namun juga berdampak pada penyelenggaraan pendidikan, dan lebih khusus pada penyelenggaraan pendidikan anak usia dini.Bahkan lebih jauh berdampak pada peserta didik (anak-anak) baik pada saat itu, maupun pada kehidupan anak tersebut kelak ketika mereka dewasa. Hal-hal tersebut tentu tidak boleh diabaikan dan dibiarkan begitu saja, diperlukan respon, antisipasi dan penanganan yang saksama dan serius, agar dampak dan risikonya dapat dikurangi bahkan ditiadakan pada tingkat yang minimum. Salah satu upaya yang dilakukan adalah penanganan secara terintegrasi melalui proses pendidikan yang sedang diikuti oleh peserta didik atau anakanak. Semakin dini dilakukan maka tentunya akan semakin baik. oleh karena itu penyelenggaraan pendidikan kebencanaan pada satuan pendidikan anak usia dini terkait materi kebencanaan menjadi sangat penting dan strategi sebagai dasar dalam mengurangi risiko atau berbagai kejadian bencana yang dihadapi.

Pendidikan kebencanaan di satuan Pendidikan Anak Usia Dini diwujudkan sebagai rangkaian upaya dalam penyelenggaraan pendidikan kebencanaandengan mengintegrasikan muatan pendidikan kebencanaan dalam kegiatan pembelajaran/ kegiatan main yang dilaksanakan di satuan atau lembaga PAUD.

Pelaksanaan pendidikan kebencanaan di satuan pendidikan anak usia dini tidak berdiri sendiri, tetapi melalui proses integrasi yang dilakukan dengan cermat dan hati-hati dan kesungguhan mulai dari perencanaan hingga evaluasinya;

Muatan pendidikan kebencanaan yang dapat diintegrasikan ke dalam kurikulum yang sedang dan akan dijalankan di satuan PAUD baik dalam mendukung enam bidang pengembangan maupun kompetensi (kompetensi inti dan kompetensi dasar) sesungguhnya sangat luas. Namun muatan materi pendidikan kebencanaan dapat dipaparkan dua hal. Pertama muatan materi pendidikan kebencanaanditujukan untuk membuka wawasan para pendidik, pengelola dan penyelenggara satuan PAUD agar mereka mengetahui ruang lingkup kebencanaan yang terjadi di Indonesia dan memudahkan mereka dalam menerapkannya saat kegiatan proses belajar mengajar. Kedua memberikan gambaran kepada anak atau peserta didik tentang proses pendidikan kebencanaan di satuan PAUD. Untuk lebih jelas diuraikan pada bagian berikut ini ${ }^{10}$ :

a. Para pendidik, pengelola dan penyelenggara dapat mengintegrasikan muatan materi pendidikan kebencanaan, jika mereka menguasai dan memiliki wawasan mulai dari konsep hingga dampak-dampaknya dari suatu bencana. Berikut beberapa materi dasar untuk dikuasai antara lain: a). konsep bencana, b). Karakteristik dan ancaman bencana, c). peta bencana di Indonesia, d). Cara-cara penanggulangan bencana, e). kesiagaan bencana, f). dampak dan penanganan reaksi anak terhadap bencana.

b. Materi pendidikan kebencanaan yang perlu diketahui sejak dini oleh anak-anak yang paling mengancam daerah-daerah di Indonesia antara lain: a). muatan materi terkait gempa bumi, b). Muatan materi terkait kebakaran gedung, c). Muatan materi terkait tsunami, d). muatan materi terkait gunung meletus, e). Muatan materi terkait banjir dan banjir bandang, f). Muatan materi terkait tanah longsor.

Ruang lingkup pengintegrasian pendidikan kebencanaan di satuan atau lembaga PAUD, antara lain:

1. Mengintegrasikan muatan pendidikan kebencanaan ke dalam KTSP atau kurikulum yang dimiliki oleh satuan PAUD

2. Mengintegrasikan muatan pendidikan kebencanaan ke dalam RPP pendidikan kebencanaan, baik pada lingkup Program Semester, Rencana Pelaksanaan Pembelajaran Mingguan (RPPM), maupun ke dalam Rencana Pelaksanaan Pembelajaran Harian (RPPH), termasuk mengintegrasikan-nya ke dalam Rencana Penilaian Perkembangan Anak.

3. Mengintegrasikan kegiatan atau aktivitas pendidikan kebencanaan ke dalam strategi/pendekatan/kegiatan main yang sudah ditetapkan atau biasa dilakukan di satuan PAUD.

4. Mengintegrasikan media dan sumber belajar pendidikan kebencanaan di PAUD (misal: poster, kartu bergambar, komik dan 
lain-lain) ke dalam kegiatan belajar atau aktivitas main anak di satuan PAUD.

5. Mengintegrasikan cara penilaian perkembangan dalam pendidikan kebencanaan ke dalam praktik penilaian yang ditetapkan atau biasa dilakukan pendidik di satuan PAUD.

6. Pelibatan pemangku kepentingan dan mitra, baik yang terkait langsung maupun tidak langsung dalam mendukung penyelenggaraan pendidikan kebencanaan di satuan PAUD.

7. Pemantauan dan penilaian pendidikan kebencanaan yang dilaksanakan di satuan PAUD melalui pembinaan, baik secara internal maupun eksternal agar penyelenggaraan pendidikan kebencanaan berjalan secara efektif, berkualitas, optimal dan dapat dipertanggungjawabkan ${ }^{10}$.

\section{KESIMPULAN}

Menyadari bahwa Indonesia merupakan negara rawan bencana, yakni bencana yang disebabkan secara geologis dan meteorologis. Semua orang mempunyai risiko terhadap potensi bencana, sehingga penanganan bencana merupakan urusan semua pihak.Penting dilakukan berbagai peran dan tanggung jawab (shareresponsibility) dalam peningkatan kesiapsiagaan di semua tingkatan baik anak, remaja dan orang dewasa.Perlu menumbuhkan kesadaran kesiapsiagaan bencana sejak dini.

Pemahaman sejak dini terhadap risiko bencana sangat penting untuk dilakukan. Upaya dalam penyelenggaraan pendidikan kebencanaan di satuan Pendidikan Anak Usia Dini yakni diwujudkan dengan mengintegrasikan muatan pendidikan kebencanaan dalam kegiatan pembelajaran atau kegiatan main yang dilaksanakan di satuan atau lembaga Pendidikan Anak Usia Dini

\section{DAFTAR PUSTAKA}

Somantri, lili. 2019, Pentingnya Pendidikan Kebencanaan di Indonesia. jp_geografi@upi.edu

BNPB: http://tirto.id/bnpb-kerugian-kerusakangempa-di-sulteng-capai-rp1382-triliunc8dx. Diunduh 15 Maret 2020

Mujiburrahman, dkk. 2019. KKN KBM Berbasis Masjid Sebagai Model Trauma Healing Berkelanjutan Pasca Gempa di Lombok Utara. LITPAM, Nusa Tenggara Barat, Indonesia. SASAMBO: Jurnal Abdimas (Journal of Community
Empowerment)

https://ejournal.litpam.org/index.php/Sasambo_ Abdimas/index e-ISSN xxxx-xxxx // Vol. 1 No. 1 September 2019, pp. 3644.

Undang-Undang Republik Indonesia No. 20 tahun 2003 tentang SISDIKNAS

Permendikbud, Nomor 137 Tahun 2014 Tentang Standar Nasional Pendidikan Anak Usia Dini.

Htttp://id.m.wikipedia.org/wiki/Pendidikan_an ak_usia_dini. Diunduh 20 Maret 2020

Permendikbud, Nomor 146 Tahun 2014 Tentang Kurikulum 2013 Pendidikan Anak Usia Dini.

BNPB, 2017. Buku Pedoman Latihan Kesiapsiagaan Bencana, Membangun Kesadaran, Kewaspadaan dan Kesiapsiagaan dalam Menghadapi Bencana, direktorat kesiapsiagaan, deputi bidang pencegahan dan kesiapsiagaan BPNP.

Undang-Undang Republik Indonesia Nomor 24 Tahun 2007 Tentang Penaggulangan Bencana

Direktorat Pembinaan Pendidikan Anak Usia Dini. Pedoman Pendidikan Kebencanaan di SAtuan PAUD. Kementerian Pendidikan dan Kebudayaan

Desfandi, M. 2014. Urgensi Kurikulum Pendidikan Kebencanan Berbasis Kearifan Lokal Di Indonesia. https://www.researchgate.net/publicatio n/295101285. Diunduh 16 Maret 2020.

BNPB, 2018. Buku Saku, Tanggap Tangkas Tangguh Menghadapi Bencana. Pusat Data Informasi dan Humas BNPB. 